\title{
Se-pronomini muodollisena subjektina suomenoppijoiden teksteissä
}

\author{
HANNA JOKELA \\ Turun yliopisto
}

Tiivistelmä. Artikkelissa tarkastellaan suomea vieraana kielenä opiskelevien teksteissä esiintyviä muodollisia subjekteja. Huomioni kohteena ovat sellaiset suomen kielen lauseet, joiden rakenteessa luonnostaan ei ole subjektia tai joissa on epätyypillinen subjekti mutta joihin oppija on lisännyt subjektin paikalle $s e$ pronominin muodolliseksi subjektiksi. Muodollinen se-subjekti, eräänlainen lisäsubjekti, ei kuitenkaan näihin lauseisiin kuuluisi. Suomen kielessä luonnostaan subjektittomia ovat esimerkiksi erilaiset tilaa ja olosuhteita kuvaavat lauseet ja epäprototyyppisiä subjektitäydennyksiä ovat esimerkiksi infinitiivi- ja lausesubjektit. Tavoitteenani on luoda yleiskuva oppijoiden muodollisen se-subjektin käytöstä, joka ansaitsee huomiota sekä suomen syntaksin että oppijankielen näkökulmasta. Tutkimukseni aineisto on kerätty kansainvälisestä oppijankielen korpuksesta. Muodollisen subjektin lauseista suurin osa on B1-B2-kielitaitotasolla (CEFR) olevien oppijoiden teksteistä, ja aineiston oppijoista suurimman osan äidinkieli on jokin indoeurooppalainen kieli. Aineistossani lisäsubjekteja löytyy etenkin skandinaavisia, germaanisia ja slaavilaisia kieliä äidinkielenään puhuvien teksteistä. Muodolliset subjektit ovat tuttuja monien oppijoiden äidinkielissä, ja suomen kielessä taas on lukuisia erityyppisiä subjektittomia rakenteita. Aiempien havaintojeni ja aineistoni perusteella suomenoppijat voivat lisätä muodollisen subjektin se sellaisissa tapauksissa, joissa lause ei rakenteensa vuoksi saa prototyyppistä subjektia, joka 
on nominatiivimuotoinen ja sijaitsee predikaatin edellä. Tällöin monikasvoinen ja tuttu se-pronomini voi saada semanttisesti tyhjän subjektielementin tehtävän.

Suomenoppijoiden tuottamat lisäsubjektilliset lauseet kuuluvat seuraaviin suomen kielen lauseryhmiin: subjektittomiin tai e-subjektillisiin erikoislausetyyppeihin ja lauseisiin, joissa subjektitäydennyksenä on infinitiivi tai sivulause. Joissakin konteksteissa muodollisia lisäsubjekteja esiintyy monilla taitotasoilla, kun taas toiset liittyvät selvemmin tiettyyn taitovaiheeseen. Etenkin säätilan ilmauksissa on eniten opintojensa alkupuolella olevien opiskelijoiden lauseita, kun taas lause- ja infinitiivisubjektillisia virkkeitä rakentavat tyypillisesti jo opinnoissaan pidemmällä olevat.

Avainsanat: ekspletiivi; infinitiivisubjekti; lausesubjekti; oppijankieli; subjekti; subjektittomuus; suomen kieli

\section{Aluksi}

Tässä artikkelissa tarkastelen se-pronominin käyttöä muodollisena subjektina, eräänlaisena lisäsubjektina, suomea vieraana kielenä opiskelevien tuottamissa suomenkielisissä teksteissä. Tutkimukseni kohteena ovat sellaiset suomen kielen lauseet, joihin ei luonnostaan kuulu kieliopillista subjektia tai joissa on epätyypillinen subjekti mutta joihin oppija on lisännyt subjektin paikalle se-pronominin muodolliseksi subjektiksi. Muodolliset subjektit ovat monille suomenoppijoille tuttuja esimerkiksi indoeurooppalaisista kielistä.

Aineistonani on Kansainvälinen oppijankielen korpus, ja aineiston tekstien kirjoittajat edustavat eri taitotasoja ja äidinkieliä. Tavoitteenani on selvittää, millaisiin lauseisiin suomenoppijat mahdollisesti lisäävät muodollisia lisäsubjekteja ja millaiset seikat muodollisen subjektin käyttöön vaikuttavat. Valaisen artikkelissani subjektin käytön ilmiöitä oppijansuomessa - kyse ei siis ole yksittäisten kielten kontrastoinnista tai taitotason kehityksen analyysista.

Kiinnostuin $s e$-lisäsubjekteista opetustyössä tekemieni havaintojen perusteella. Olen havainnut, että muodollisia subjekteja voi löytää eri 
taitotasoilla olevien ja eri äidinkieliä puhuvien opiskelijoiden teksteistä. Muodollisia lisäsubjekteja esiintyy monilla taitotasoilla, mutta joissakin tapauksissa niitä käyttävät innokkaimmin esimerkiksi alkeisoppijat.

Oletan, että suomenoppijat pyrkivät lisäämään ylimääräisen subjektin, kun lause ei rakenteensa vuoksi saisi prototyyppistä subjektia, joka on verbinetinen ja nominatiivimuotoinen ja helposti hahmotettavissa subjektiksi. Suomessa luonnostaan subjektittomia ovat esimerkiksi erilaiset tilaa ja olosuhteita kuvaavat lauseet (On kylmä. ${ }^{\star}$ Se on kylmä.). Epätyypillisiä subjektitäydennyksiä puolestaan ovat esimerkiksi eksistentiaalilauseen partitiivimuotoiset subjektit (Salissa on opiskelijoita. ${ }^{*}$ Se on opiskelijoita salissa) sekä infinitiivi- ja lausesubjektit. Muodolliseksi lisäsubjektiksi valitaan monikäyttöinen se-pronomini. (Edellä olevat kielenvastaiset esimerkit ovat omiani, ja ne on mukailtu aineistoni tapauksista.) Erilaiset lausetyypit ja -rakenteet ohjaavat subjektin hahmottamista ja käyttöä. Ilmiö ansaitseekin huomiota sekä suomen kielen syntaksin että oppijankielen näkökulmasta.

Puhutussa kielessä myös suomen kielen se-pronominilla on muodollisen subjektin kaltaista käyttöä, kuten esimerkiksi lauseessa Se on kesä nyt. Suomen muodollista subjektia pidetään epämuodollisen puhutun kielen ilmiönä (Vilkuna 1996: 150). Tässä tutkimuksessa tarkastellaan kuitenkin kirjoitettua kieltä ja suomen kielen rakenteen vastaisia ylimääräisiä lisäsubjekteja. Muodollisen subjektin terminologia on monimuotoinen sekä suomen kielen tutkimuksessa että kansainvälisesti (ks. luku 3). VISK: käsittelee muodollista subjektia ja ekspletiivisubjektia synonyymeina (VISK: $₫ 915$; VISK määritelmät). Käytän oman aineistoni esiintymistä ilmausta muodollinen lisäsubjekti.

Artikkelini on jäsennelty siten, että esittelen aineistoa ja sen lähestymistapoja luvussa 2. Luvussa 3 tarkastelen subjekteja ja subjektittomuutta ja niiden määrittelyä sekä tutkimuksessa että S2-oppijoiden opetuksessa. Luku 4 esittelee erilaiset muodollisen lisäsubjektin käyttötapaukset ryhmittäin, ja luvussa 5 teen koontia aineistoni tapauksista. 


\section{Aineisto ja näkökulma}

Aineistoni koostuu Kansainvälisestä oppijankorpukseksesta (ICLFIkorpus) kerätyistä lauseista, joissa on välittömästi olla-verbin yksikön 3. persoonan muodon on edellä se-pronomini muodollisena lisäsubjektina. Korpuksesta on ensin haettu kaikki se on -lauseet. Sen jälkeen lauseista on poimittu mukaan ne, joissa se on nimenomaan ylimääräisenä lisäsubjektina, ei siis referentiaalisesti demonstratiivipronominin tehtävässä. Korpusaineistossa on 105 tällaista se on -lausetta. Kaikkiaan se on -lauseita korpuksessa on 1 525. Tutkimusaineistoni koostuu lauseista, joissa predikaattina on preesensmuotoinen verbi. Tarkastellun ilmiön kannalta aikamuoto tuskin on oleellinen muuttuja; mahdollisissa jatkotutkimuksissa on mahdollista huomioida muutkin aikamuodot.

Aineistoni lauseet ovat useiden eri äidinkielten puhujien tuottamia. Oppijoiden äidinkielet ovat ruotsi (lauseita yhteensä 22), venäjä (12), saksa (11), hollanti (10), unkari (9), tšekki (9), kiina (8), islanti (7), puola (7), espanja (5), italia (4) ja ranska (1). Aineistossa on lauseita taitotasoilta A1-C1. Taitotasot viittaavat Eurooppalaisen viitekehyksen (CEFR) kuvauksiin. Korpuksen taustatiedoissa taitotaso on määritelty jokaisen oppijan kohdalla opetetun tuntimäärän sekä Eurooppalaisen viitekehyksen perusteella (Jantunen 2011: 92). Muodollisen lisäsubjektin lauseista $36 \%$ on A1-A2-taitotason opiskelijoiden teksteistä, $61 \%$ B1-B2-taitotason oppijoiden teksteistä ja $3 \%$ C1-taitotason oppijoiden teksteistä. Artikkelissani viittaan edistyneillä oppijoilla sellaisiin oppijoihin, jotka ovat opinnoissaan edenneet jo alkuvaihetta pidemmälle, B2-tasolle ja siitä eteenpäin.

Tutkimuksessani hyödynnetty kansainvälinen oppijankorpus sisältää luokkahuonetilanteissa tai kotitehtävinä laadittuja kirjoitelmia usean eri äidinkielen oppijalta; korpusta täydennetään edelleen. Aineisto on koottu ulkomaisissa suomen kielen opetuspisteissä, joten kyseessä on nimenomaan vieraan kielen aineisto. (Jantunen 2011: 92) Korpuksessa on tällä hetkellä hieman yli miljoona sanetta (ICLFI). ILCFI 
sisältää kattavasti taustatietoa tekstien tuottajista ja teksteistä (Jantunen 2011: 93), mitä voi pitää korpusaineiston etuna.

Suomea toisena ja vieraana kielenä tutkittaessa korpuksia on hyödynnetty eri taitotasojen kehityksen vertailussa sekä äidinkielisten suomenpuhujien että S2-oppijoiden piirteiden vertailussa. Esimerkiksi Jantunen (2013) on verrannut astemääritteiden (melko, aika, hyvin, tosi) käyttöä suomea suomessa ja suomea ulkomailla opiskelevien sekä toisaalta äidinkielisten kielenkäytössä. Ivaska $(2014,2015)$ selvittää oppijansuomelle tyypillisiä rakenteita ja niiden käyttöä ja yleisyyttä avainrakenneanalyysin avulla ja vertaa oppijansuomen ja natiivien tuottaman suomen tyypillisiä piirteitä. Jantunen (2015: 106) toteaa ensikielen vaikutuksen ja kielitaidon kehityksen olleen keskeisiä tutkimuskohteita sekä oppijankorpuksia hyödyntävässä tutkimuksessa että aikana ennen oppijankorpuksia.

Omassa aineistossani olen kiinnittänyt huomiota äidinkieleen ja korpuksessa arvioituun taitotasoon, jotka ovatkin korpuksen käytetyimmät muuttujat (Jantunen 2015: 94). Eri oppimiskonteksteja, siis suomi toisena kielenä tai suomi vieraana kielenä -opiskeluympäristöjä (ks. esim. Jantunen 2015: 108), omassa tutkimuksessani ei vertailla, koska aineisto on kokonaan suomi vieraana kielenä -aineisto.

Muodolliset subjektit ovat tavallisia indoeurooppalaisissa kielissä, ja niitä ja suomen subjektittomia rakenteita on tarkasteltu kontrastiivisesti (ks. luku 3.3), ja kontrastiivinen lähestymistapa on tämänkin tutkimuksen taustalla. Artikkelissa käsiteltävät ilmaukset ovat hahmotettavissa eräänlaisiksi konstruktioiksi. Eri konstruktioille on ominaista kielikohtaisuus, mutta vaikka konstruktiot ovat kielikohtaisesti spesifejä rakenteita morfosyntaktisesti, niitä voi vertailla kieltenvälisesti niiden tehtävien mukaan (Croft 2001: 50-51). Koska tutkimuskohteena olevien lauseiden määrä on suppea ja koska oppijoiden äidinkieliä on useita, yksittäisen äidinkielen ja suomen välillä ei ole mahdollista tehdä yksityiskohtaista kontrastiivista analyysia. Oletan kuitenkin opetuskokemukseni perusteella, että esimerkiksi skandinaavisten ja germaanisten kielten puhujilla on se-pronomineja muodollisina subjekteina. 
Kielitaidon kehityksen ja tasojen vertailu edellyttäisi laajempaa jatkotutkimusta, mutta tässä artikkelissa kiinnitän huomiota siihen, ovatko jotkin muodollisen lisäsubjektin tapaukset tyypillisiä jossakin tietyssä taitoryhmässä. Tarkoitukseni on luoda yleiskuva muodollisen subjektin ja subjektin ominaispiirteisiin liittyvistä ilmiöistä oppijansuomessa.

\section{Erilaiset subjektit ja subjektittomuus}

\subsection{Suomen subjekti}

Kieltenvälisesti subjekti määritellään predikaattiverbin merkittävimmäksi argumentiksi temaattisin, morfosyntaktisin ja topikaalisin perustein (Svenonius 2002: 3-4). Typologisessa tarkastelussa subjektin kriteereinä pidetään sijan merkintää, kongruenssia ja sanajärjestystä (ks. Helasvuo \& Huumo 2010: 15).

Suomen kielen kuvauksessa voidaan erottaa kolme subjektin lajia sijamuodon ja kongruenssin toteutumisen mukaan. Nominatiivisubjektia VISK nimittää perussubjektiksi, ja se kongruoi finiittiverbin persoonan ja luvun suhteen. Kongruenssia VISK pitääkin vahvimpana subjektikriteerinä. (VISK: $₫ 910$ ) Tyypillisellä subjektilla on agentin ominaisuuksia. Eksistentiaalilauseen subjektia VISK nimittää e-subjektiksi. E-subjektin sijamuoto on partitiivi, mikäli sen tarkoite on jaollinen, ja perussubjektista poiketen e-subjekti sijoittuu lauseessa verbin jälkeen. Nesessiivirakenteissa ja infiniittisissä rakenteissa subjektina on genetiivisubjekti. (VISK: \$ 910) VISK katsoo myös lauseet ja infinitiivirakenteet subjekteiksi, mikäli niiden "suhde verbiin on samanlainen kuin NP-subjekteilla”. Näissä subjektitapauksissa ei toteudu nominatiivimuotoisuus eikä kongruenssi. (VISK: \$ 911) Genetiivi- ja partitiivimuotoisten subjektien sisällyttämiseen subjektin kategoriaan on suhtauduttu tutkimuksessa myös kriittisesti. Helasvuo ja Huumo toteavat, että genetiivi- tai partitiivimuotoiset sekä lause- ja infinitiivimuotoiset subjektit eivät täytä sijamuotokriteeriä tai laukaise kongruenssia. Niille ei myöskään sovellu agentin semanttinen rooli, sillä ne eivät tavallisesti kuvaa tilanteita, joissa on agentiivinen osallistuja subjektina. (Helasvuo \& Huumo 2010: 167) 
Subjektin perusteella suomen lausetyypit voi jakaa kahteen pääryhmään. Toisen pääryhmän muodostavat ne, joihin kuuluu nominatiivimuotoinen ja kongruenssin laukaiseva perussubjekti. Näitä on nimitetty esimerkiksi normaalilauseiksi (Hakanen 1972) ja monikäyttöisiksi lausetyypeiksi (VISK: \$ 819). Toiseen pääryhmään kuuluvat lauseet, joissa subjektia ei ole tai joiden subjekti ei ole prototyyppinen perussubjekti. Tämän ryhmän lauseet kuuluvat muun muassa VISK:n (\$ 819) mukaan erikoislausetyyppeihin. S2-oppijan on tärkeää tunnistaa predikaattiverbin täydennykset. Leila White esittelee (2010: 240-242) S2-oppijoille suunnatussa kieliopissaan subjektin sijamuotoina nominatiivisubjektin, partitiivisubjektin ja genetiivisubjektin; näistä kaksi jälkimmäistä rajautuu hänen mukaansa vain tiettyihin lausetyyppeihin.

\subsection{Suomen subjektittomuus}

Subjekti on verbin täydennys mutta kaikissa lauseissa sitä ei ole. Subjekti voi olla ilmipanematon (esim. Puhun suomea) tai subjekti voi rakenteellisesti luonnostaan puuttua. Luonnostaan subjektittomia lausetyyppejä ovat säätä, olosuhteita ja tuntemuksia ilmaisevat tilalauseet. Rakenteellisesti subjekti puuttuu myös passiivi- ja nollapersoonalauseista, ja imperatiivin 2. persoona on tyypillisesti subjektiton. (VISK: $₫ 913,914$ ) Luonnostaan subjektittomatkin tapaukset ovat toki keskenään varsin erilaisia. Nollapersoonan tyyppisiin tapauksiin voidaan teknisesti kuvitella jokin kolmaspersoonainen subjekti, säälmauksiin se ei kuulu.

Koska huomioni on nimenomaan oppijansuomen lauseissa, olen perehtynyt myös S2-oppijoille tarkoitettujen oppikirjojen ja kielioppien subjekti-ilmiöiden käsittelyyn. Monissa ulkomaisissa yliopistoissa käytössä oleva Suomen mestari -oppikirjasarja ei käsittele subjektittomuutta tai tekijän puuttumista erillisenä teemana, mutta kirjasarjan kappaleissa esitellään erilaisia rakenteita ja lausetyyppejä, joiden yhteydessä subjektin puuttumista tai sijaa kommentoidaan. Suomen mestari 1 -oppikirja (kattaa taitotason A1) esittelee sääilmauksia kappaleessa 3. Kappaleessa opetellaan lämpötilan ilmaisemista ja säästä kertomista. Tässä vaiheessa 
ei kommentoida lauserakenteita, mutta esimerkit kattavat tyypillisiä subjektittomia sääilmauksia: Sataa. Tuulee. On kuuma. Suomen mestari 1 esittelee eksistentiaalilauseen rakenteen oppikirjan kappaleessa 6, jossa käsitellään paikallissijojen käyttöä. Oppikirjassa puhutaan Huoneessa on -rakenteesta. Subjektia tai muita lauseenjäseniä ei nimetä. Suomen mestari 1 esittelee sisällysluettelossa tilalauseeksi nimetyn on hauskaa -lausetyypin kappaleessa 7. Esimerkeissä esitellään virheellisenä tapaus, jossa on kielenvastainen se-subjekti: Se on hauskaa olla lomalla. Suomen mestari 2 -oppikirja käsittelee kappaleessa 2 nollapersoonan, jossa tekijän puuttuminen tuodaan esiin.

White (2010: 245) listaa S2-oppijoille suunnatussa kieliopissaan keskeiset subjektittomat tapaukset, jotka ovat passiivi (Kirja käännettiin ruotsiksi), geneeriset lauseet (Täällä voi opiskella suomea), säätä kuvaavan verbin sisältävät lauseet (Sataa), tunnetta tai fyysistä olotilaa kuvaavat lauseet (Päätä särkee) sekä jonkin paikan tai ajankohdan ilmapiiriä kuvaavat lauseet (Italiassa oli ihanaa). White tuo tässä yhteydessä esiin myös "On hauskaa"-lauseet ja lisää, että näiden yhteydessä suomessa voi esiintyä infinitiivisubjekti tai lausesubjekti: On hauskaa lähteä lomalle. Oli mukavaa, että sait töitä. White lisää, että toisin kuin monissa indoeurooppalaisissa lauseissa suomessa tällaisten lauseiden alkuun ei pidä lisätä pronominia se. (White 2010: 245)

Oppijansuomen subjektittomiin ilmauksiin on kiinnitetty huomiota tutkimuksessa aiemminkin. Siitonen (2002) käsittelee ilmisubjektittomuutta edistyneiden oppijoiden nollapersoonalauseiden käytön kannalta. Suomen nollapersoonaa ja passiivia ja niiden käyttöä oppijankielessä käsittelevät Seilonen (2013) sekä Ivaska (2014), joka tarkastelee mahdollisuuden ilmaisemista nollapersoona- ja passiivimuotoisten modaaliverbien avulla oppijansuomessa ja äidinkielisessä suomessa. Kuvaa oppijansuomen subjektista on hyvä täydentää tarkastelemalla oppijoiden pyrkimystä muodollisten subjektien käyttöön. 


\subsection{Muodolliset subjektit kontrastiivisesti}

Muodolliset subjektit voivat olla pronomineja ja deiktisiä adverbeja, ja niistä on käytetty kansainvälisessä kirjallisuudessa useita nimityksiä, esimerkiksi dummy subjects, formal subjects ja pleonastic subjects (Eriksen ym. 2015). Fennistiikassa muodollista subjektia ja ekspletiivisubjektia käytetään nimityksinä myös synonyymisesti (VISK: $₫ 915$ ). Muodollisten subjektien oleellinen ominaisuus on semanttinen tyhjyys (Svenonius 2002: 5), ja muodollisia subjekteja käytetään lauseissa, joissa subjektin paikalle ja tehtävään ei ole tarjolla leksikaalista elementtiä. Subjektin paikka täytetään epäreferentiaalisella elementillä. (Eriksen ym. 2015: 213) Kieltenvälisessä tarkastelussa ekspletiivit jakautuvat kahteen tyyppiin. Pronominiekspletiivit ovat referentiaalisesti tunnusmerkittömiä, kuten skandinaavisten kielten det tai ranskan $i l$. Adverbiaaliset ekspletiivit ovat kehittyneet deiktisistä adverbeista (esim. here and there). (Eriksen ym. 2015: 214)

Indoeurooppalaisten kielten muodollisten subjektien käyttötapausten vastineet suomessa ovat usein subjektittomia rakenteita. Kontrastiivisessa tarkastelussa Tarvainen (1985: 35-36) esittelee suomen ja saksan subjektin tyyppi- ja muotoeroja. Hän toteaa, että saksassa on kaksi subjektityyppiä, joita suomessa ei ole: ensimmäinen on "anonyymi henkilösubjekti" man, ja toinen muodollinen subjekti es (Jetzt ist es noch warm 'Nyt on vielä lämmintä). Löflundin (1998: 161) mukaan suomen nollapersoonalausetta vastaa merkitykseltään ruotsin man-konstruktio, ja Tenhonen-Lightfoot (1992: 46) pitää saksan kielen geneeristä mankonstruktiota suomen nollapersoonan vastineena. Helasvuo ja Johansson (2008) kontrastoivat suomen nollapersoonarakennetta ja passiivia ranskan on-rakenteeseen ja passiiviin.

Eriksen, Kittilä ja Kolehmainen (2015: 213) toteavat, että muodolliset subjektit sääilmauksissa vaikuttavat erityisen tyypillisiltä pohjoisessa Euroopassa puhuttavissa kielissä, joskin tämä vaatii tarkempaa tutkimusta. Sääilmausten subjektit ovat tyypillisesti epäreferentaalisia, indefiniittisiä, ei-topikaalisia, elottomia tai ei-agentiivisia, joten niiden 
voi todeta olevan epätyypillisiä subjekteja. Sääilmauksissa osallistujat voivat olla epätarkkoja, mutta kielillä näyttää olevan tarve luoda rakenteisiin osallistujaa ilmaisevat elementit. (Eriksen ym. 2015: 226) Tämä on tutkimukseni kannalta kiinnostavaa, sillä sääilmausten muodolliset subjektit ovat tavallisia myös monien aineistoni lauseiden tuottajien äidinkielissä.

\subsection{Suomen se muodollisena subjektina}

On huomattava, että puhutussa suomessa se-pronominilla voi olla muodollisen subjektin kaltaista käyttöä, kuten seuraavissa Holmbergin ja Nikanteen (2002: 76) esimerkeissä: Nyt se taas sataa. Se oli hauskaa, että tulit käymään. Puhutun kielen tapaukset on syytä erottaa suomen kielen rakenteen vastaisista lisäsubjekteista, joita tarkastelemassani oppijansuomessa esiintyy. On varsin epätodennäköistä, että tutkimusaineistoni ulkomailla suomea opiskellut oppija olisi poiminut puhutun kielen se-pronominisubjekteja puheesta.

Kun puhutussa suomessa käytetään muodollista subjektia, tehtävässä toimii painoton se-pronomini, jolla ei ole anaforista eikä demonstratiivista tehtävää. (VISK: $\$ 915$ ) VISK (\$ 915) kuvaa muodollista subjektia elementiksi, "jonka tehtävänä on täyttää subjektin paikka silloin, kun subjekti puuttuu tai on rakenteeltaan sellainen, ettei se luontevasti sijoitu subjektin paikalle". Se-pronomini muodollisen subjektin paikalla on mahdollinen myös affektiivisessa käytössä. Affektiivinen tulkinta voi syntyä konteksteissa, joissa esimerkiksi moitiskellaan tai kehuskellaan: Monet sanoivat, että taso on kohenemassa vuosi vuodelta, mutta minä se vain säilyn ykkösenä, [---]. (VISK: \$1715).

Se-pronominin lisäksi sitä-partikkelilla voi olla muodollisen subjektin tehtäviä. Sitä-partikkelilla on sekä passiivilauseessa (Sitä eletään toki vähemmälläkin) että nollapersoonalauseessa kieliopillisena funktiona täyttää muuten tyhjäksi jäävä nominin paikka (Sitä ei saisi puuttua kenenkään yksityisasioihin) (Hakulinen 1975: 29, 32-33; Laitinen 1995: 339). Holmberg ja Nikanne (2002: 72) käsittelevät suomen monisubjektisia 
rakenteita (engl. Multiple Subject Constructions) ja toteavat, että suomessa on tapauksia, joissa samassa lauseessa on ekspletiivinen ja leksikaalinen subjekti: Sitä ovat nämä lapset oppineet jo uimaan. Holmberg ja Nikanne (2002: 90) pitävät sitä-pronominia puhtaasti muodollisena subjektina (ekspletiivinä), koska sillä ei ole subjektimaisia mahdollisuuksia varioida sijan ja kongruenssin mukaan mutta se täyttää kieliopillisesti täytefunktion.

Kolehmainen (2010: 6) tarkastelee suomen sääverbejä ja huomauttaa, että suomen sääverbien kuvauksen keskiössä on subjektittomuus. Esimerkiksi Vilkuna (1996: 133) luonnehtii säätilalauseita "syvällisesti" subjektittomiksi. Kolehmainen (2010: 8) tarkastelee se-pronominin esiintymistä sääverbien yhteydessä selvittääkseen sen kehittymistä muodolliseksi subjektiksi. Kolehmaisen aineiston perusteella muodollinen subjekti ei ole levinnyt kirjoitetussa kielessä sääverbien yhteyteen, sillä tapauksia, joissa on viitteitä se-pronominin käytöstä muodollisena subjektina sääverbin yhteydessä, on vain yksittäisiä.

\section{Muodolliset lisäsubjektit aineistossa}

Havaintojeni ja aineistoni perusteella suomenoppijat voivat lisätä ylimääräisen subjektin sellaisissa tapauksissa, joissa lause ei rakenteensa vuoksi saa prototyyppistä subjektia. Aineiston esiintymät löytyvät taulukosta 1.

TAulukко 1. Aineiston lisäsubjektit

\begin{tabular}{|l|r|}
\hline Infinitiivisubjektilliset lauseet & 45 \\
\hline Subjektittomat tilalauseet & 31 \\
\hline Lausesubjektit & 21 \\
\hline Eksistentiaalilauseet & 8 \\
\hline Yhteensä & 105 \\
\hline
\end{tabular}


Kuten aineiston koostumuksen esittelystä luvussa 2 selviää, lauseet ovat pääosin indoeurooppalaisten kielten puhujien tuottamia. Ruotsinkielisisten oppijoiden lauseita 20 yhteensä (15 eri oppijaa), saksankielisten lauseita 11 (10 eri oppijaa) ja hollaninkielisten lauseita 10 (8 eri oppijaa). Venäjänkielisten oppijoiden lauseita on 12 (9 eri oppijaa). Indoeurooppalaisen ryhmän ulkopuolelta on mukana äidinkielisen 9 unkarilaisen (yhteensä 5 eri oppijaa) ja 8 äidinkielisen kiinalaisen (yhteensä 5 eri oppijaa) tekstistä peräisin olevaa lausetta. Lähisukukieltä viroa äidinkielenään käyttäviä oppijoita lauseiden kirjoittajissa ei ole. Vaikka (ilmi)subjektin käytössä on joitakin eroja suomessa ja virossa, kummassakaan kielessä ei käytetä demonstratiivista pronominia muodollisena subjektina.

Tarkastelen seuraavissa luvuissa muodollisen lisäsubjektin tapauksia ryhmittäin. Ensin tarkastellaan erikoislausetyypeistä subjektittomia tilalauseita ja sen jälkeen eksistentiaalilauseita. Näiden jälkeen käsitellään lauseita, joissa subjektitäydennyksenä on infinitiivi tai sivulause.

\subsection{Subjektittomat tilalauseet}

Ensimmäiseksi valitsemani ryhmä oppijoiden lisäsubjektillisia lauseita kattaa erilaisia säätilaa, olosuhteita ja tilannetta kuvailevia lauseita. Lauseet ovat tuottaneet espanjan, hollannin-, italian-, puolan- ja saksankieliset oppijat. Aineistossa on yhteensä 31 tilalausetta, joista 20 lausetta on A1- tai A2-tasoilla olevien ja 9 lausetta tasolla B1 olevien opiskelijoiden tuottamia ja 1 lause on B2-taitotason ja 1 C1-taitotason opiskelijan tuottama. Kaikkia ryhmän lauseita yhdistävät subjektittomuus ja predikatiivillisuus. Kaikissa lauseissa on predikaattina olla-verbi, joka onkin yleisin tilalauseiden predikaattiverbi (VISK: $₫ 901$ ). Tilalauseessa tavallisesti teemapaikassa on paikkaan, ajankohtaan tai tilanteeseen viittaava adverbiaali, tai teemapaikka voi olla tyhjä (VISK: $\$ 900$ ). Aineistoni tilalauseisiin suomenoppijat ovat kuitenkin lisänneet verbinetiselle paikalle muodollisen $s e$-lisäsubjektin.

Tilalauseessa voi predikatiivina esiintyä adjektiivin lisäksi substantiivi, joka viittaa säähän tai ajanjaksoon, kuten vuodenaikaan tai 
juhlapyhään (Nyt on tulee hyvä ilma hyvä hiihtokeli aamu kesä $\sim$ kaunis kesäpäivä maanantai pääsiäinen Tiinan syntymäpäivä vuosi 1998) (VISK: § 901). Aineistoni tilalauseissa on sekä adjektiivi- että substantiivipredikatiivillisia lauseita. Teksteissään oppijat mm. kuvailevat paikkoja sekä tiloja ja juhlapyhien viettoa. Adjektiivipredikatiivilliset lauseet viittaavat jonkin ajankohdan tai paikan luonteeseen tai tilaan. Näin on esimerkkilauseissa (1-3), joissa esiintyy adjektiivipredikatiivi (mukava, kaunis, rauhallinen). Esimerkeissä (1-3) sopiva predikatiivin sija olisi partitiivi - predikatiivin sijanvalinta on suomenoppijoille hyvin tavallinen ongelma monilla taitotasoilla (ks. Laine 2013). Predikaattiverbin edellä on muodollinen se-lisäsubjekti teemapaikkaisesta adverbiaalista (pääsiäisenä, Göttingenissä, missä) huolimatta. Esimerkit edustavat tyypillisiä oppijoiden lisäsubjektillisia tilalauseita ja ovat A2ja B1-taitotasoille määriteltyjen oppijoiden tuottamia.

Esimerkki (4) on hollanninkielisen ja esimerkki (5) ruotsinkielisen oppijan tekstistä. Esimerkeissä (4) ja (5) tilalause alkaa konjunktiolla, jonka jälkeen predikaatin edelle on lisätty muodollinen lisäsubjekti se. Esimerkissä (4) on substantiivipredikatiivi syntymäpäiväni ja esimerkissä (5) substantiivipredikatiivi lauantai.

(1) Pääsiäisenä se on mukava, koska minulla on vapaa-aika. (tšekki, B1)

(2) Göttingenissä se on kaunis, mutta vielä kallis. (saksa, A2)

(3) Pidän että että ei ole vaikea löytää paikka missä se on rauhallinen. (islanti, A2)

(4) Kun se on minun syntymäpäiväni, minä kysyn aina käntännöllistä käyttöesinen. (hollanti, A2)

(5) Koska se on lauantai, minä puen vaatteet päälle aika myöhään. (ruotsi, B2)

Tällaiset kuvailevat ja näkökantoja esittelevät lauseet ovat tavallisia, mutta prototyyppisen subjektin puuttuminen ja samalla koko lauseen jäsentyminen voi olla oppijalle outo ilmiö, sillä monissa kielissä tällaisissa tapauksissa on jokin muodollinen subjekti predikaatin edellä.

Aineistoni tilalauseissa on 18 vallitsevaa säätilaa ja lämpötilaa ilmaisevaa lausetta, joiden ominaispiirteisiin kuuluu subjektittomuus mutta 
joihin oppijat ovat lisänneet predikaatin täydennykseksi se-pronominin subjektin tyhjälle paikalle. Nämä lauseet ovat taitotasoilla A1, A2 ja B1 olevien oppijoiden tuottamia. Edistyneemmän taitotason oppijoilla muodollisen subjektin sisältäviä säälauseita ei ole. Lisäsubjektillisista säätilalauseista puolet eli 9 on (yhteensä 8 eri oppijaa) ruotsinkielisen suomenoppijan tuottamia. Äidinkieleltään ruotsinkielinen oppija pyrkii se-pronominilla täyttämään mahdollisesti muodollista det-subjektia vastaavan suomen tyhjänä olevan subjektin paikan. Säätilaa kuvaavissa tilalauseissa predikaatin on jäljessä on adjektiivi, joka kuvaa säätilaa ja olosuhteita, kuten esimerkkien (6) ja (7) kylmä. Esimerkissä (6) oppija ei ole erottanut kun-konjunktiolla alkavaa sivulausetta päälauseesta välimerkein, mutta tulkitsen lauseen siten, että se viittaa yleiseen lämpötilaan tai sääoloihin. Suomenoppijalle ei liene valjennut, että suomessa on tyypillistä sanoa, että ulkona on kylmä, tai deiktisellä adverbilla todeta, että siellä on kylmä. Esimerkeissä (8) ja (9) on kyse kahdesta eri B1-taitotasoisesta oppijasta, joiden äidinkieli on ruotsi. Esimerkkilauseet kuvaavat lämpöasteita. On kiinnostavaa huomata, että esimerkissä (8) informantti osoittaa hallitsevansa sääverbiin tuulla liittyvän subjektittomuuden. Myöskään esimerkkien (8) ja (9) substantiivipredikaatillisissa Tänään-lauseissa ei ole muodollista se-subjektia predikaatin edellä.

(6) Kun herän aamulla se on kylmä. (A1, ruotsi)

(7) Maisema on lumen peitossa ja se on hyvin kylmä. (saksa, B1)

(8) Tänään on nyt viileä ilma, se on plus 2 astetta ja vähän tulee. (ruotsi, B1)

(9) Tänään on hieno ilma, aurinko paistaa ja se on 25 astetta plus. (ruotsi, B1)

Artikkelissani keskityn olla-predikaatillisiin lauseisiin, mutta sääilmausten kiinnostavuuden vuoksi olen käynyt läpi myös sellaiset korpuksen lauseet, joissa predikaattina on kolmaspersoonainen sataa. Korpuksesta löytyykin yksi sataa-predikaatillinen lause, jossa on muodollinen lisäsubjekti (se sataa). Lause on A1-tasolla olevan äidinkieleltään ruotsinkielisen oppijan tekstistä. Toki sääverbien subjektittomuus tulee oppijalle melko nopeasti tutuksi, mutta erilaisia tiloja ja olosuhteita 
kuvaavissa lauseissa on tapauksia, joiden subjekti tai sen puuttuminen voi olla epäselvä edistyneemmällekin oppijalle.

\subsection{Eksistentiaalilauseet}

Oppijoiden lisäsubjektilliset tilalauseet edellä antavat viitteitä siitä, että oppijan voi olla vaikea hahmottaa, että lauseesta voi puuttua prototyyppinen - nominatiivimuotoinen, kongruoiva ja verbinetinen - subjekti. Seuraavassa tarkasteltaviin eksistentiaalilauseisiin saattaa liittyä samantyyppisiä haasteita, sillä niissäkään ei suomen kielessä (tavallisesti) ole predikaattiverbin edellä nominatiivimuotoista subjektia teemapaikalla.

Eksistentiaalilauseen rakenne on monelle suomenoppijalle oman äidinkielen vastaaviin lauseisiin verrattuna vieras, sillä monissa kielissä jossakin on jotakin -tyyppisessä esittelylauseessa on muodollinen subjekti tai vastaava elementti; esimerkiksi esittelylauseessa There is a dog in the garden on deiktinen elementti (Eriksen ym. 2014: 213). Suomessa lokaalinen adverbiaali on lauseenalkuisessa asemassa ja subjektitäydennys puolestaan predikaattiverbin jäljessä.

Aineistossani on 8 sellaista eksistentiaalilausetta, joissa olla-predikaatin edellä on muodollinen subjekti se. Näistä 6 on A2-oppijoiden tuottamia ja A1- kuten myös B1-tason oppijalta on 1 kummaltakin. Lauseista 3 on tuottanut sama islanninkielinen opiskelija; loput kirjoittajat ovat ruotsin-, ranskan- tai saksankielisiä.

Aineiston eksistentiaalilauseissa on pyritty käyttämään suomen kielen prototyyppisen muotoista subjektia ja prototyyppistä subjektin ja predikaatin järjestystä. Predikaattiverbin edelle on sijoitettu lisäsubjektiksi muodollinen se-subjekti. Oppijoiden tuottamissa lauseissa paikkaa ilmaiseva adverbiaali on lauseen alussa (esimerkki 10) tai lauseen lopussa (esimerkki 11). Näyttää alustavasti siltä, ettei lokaalisella adverbiaalilla eikä sen sijainnilla ole välttämättä vaikutusta siihen, halutaanko muodollista subjektia käyttää. Esimerkissä (10) on kiinnostavaa se, että eksistentiaalilauseen subjekti on yksikössä ja nominatiivimuotoinen (tistikone), mutta oppija on silti lisännyt se-subjektin verbin edelle. 
Esimerkissä (11) oppija on ehkä tarkoittanut monikkomuotoa konsertteja, joka olisi lauseen e-subjekti. Oppijan lauseessa paikan adverbiaali Reykjavikissa on e-subjektin jäljessä ja predikaattiverbin edellä on nominatiivimuotoinen lisäsubjekti se.

(10) Tyohuonessa se on yksi tistikone. (ranska, A1)

(11) Pidän että se on paljon konsertia Reykjavikissa ja menen joskus konsertiin. (islanti, A2)

Suomenoppijoiden eksistentiaalilauseen hallinta on kiinnostanut tutkijoita. Ivaska (2014) tarkastelee edistyneiden oppijoiden lausetyyppejä erityisesti eksistentiaalilauseiden tunnistamisen näkökulmasta. Kajander (2013) tarkastelee eksistentiaalilauseiden sujuvuutta ja tarkkuutta eri taitotasoilla. Kajander kiinnittää huomiota etenkin e-NP:n sijaan, lokatiiviseen elementtiin ja verbiin. Kajander (2013: 71) myös huomauttaa, että muutamissa hänen aineistonsa lauseissa on ns. subjektin paikanpitäjänä se-pronomini.

\subsection{Infinitiivisubjektilliset lauseet}

Monissa kielissä voi esiintyä muodollinen subjekti infinitiivi- ja lausesubjektin yhteydessä. Tästä sopii esimerkiksi Eriksenin ym. (2014: 213) lause It is hard to analyze such constructions. Vastaavia rakenteita löytyy monista indoeurooppalaisista kielistä, eivätkä ne voisi olla verbialkuisia. Suomen kielessä vastaava lause On vaikea analysoida tällaisia rakenteita sen sijaan on verbialkuinen. Suomenoppijoiden voi olla vaikea hahmottaa tällaisten ja seuraavassa luvussa käsiteltävien lausesubjektillisten tapausten verbinalkuisuutta, ja opinnoissaan jo pidemmälläkin olevat oppijat pyrkivät lisäämään lauseisiin muodollisen se-lisäsubjektin. Lauseilla on yhteisiä piirteitä tilalauseiden kanssa.

Seilonen (2013: 114) kiinnittää omassa tutkimuksessaan huomiota on kiva -lauseisiin, jotka ovat Seilosen mukaan oppijansuomessa eri taitotasoilla lähes alusta asti varsin oikein. Seilosen mukaan tyypillisin epätarkkuus oppijoiden rakenteissa on muodollinen subjekti juuri 
näissä lauseissa: se on viakea pasta ulos (Seilonen 2013: 117). Samankaltaisia huomioita olen itsekin tehnyt.

Aineistossani on yhteensä 45 sellaista lausetta, joissa subjektina on A-infinitiivi ja johon oppija on lisännyt muodolliseksi lisäsubjektiksi sepronominin. Infinitiivisubjektillisiin lauseisiin lisäsubjektin se lisänneet oppijat ovat tasoilla A1 (1), A2 (10) sekä B1 (34). Aineistoni perusteella infinitiivisubjektiin liitetyt muodolliset $s e$-pronominit eivät ole ensisijaisesti alkeistason ilmiö, mikä todennäköisesti johtuu siitä, ettei tällaisia virkkeitä tuoteta aivan opintojen alkuvaiheessa. Siitonen ja Martin (2012) ovat todenneet tiettyjen virheiden olevan korkeampien taitotasojen indikaattoreita.

Esimerkit (12-15) ovat B1- ja B2-oppijoiden teksteistä. Kaikissa niissä olla-predikaattiin liittyy adjektiivipredikatiivi ja subjektina on infinitiivilauseke, jonka lisäksi oppijat ovat lisänneet muodollisen sesubjektin olla-predikaattiverbin edelle. Tekstien kirjoittajat arvioivat toiminnan vaarallisuutta (esimerkki 12) tai vaikeutta (esimerkit 13-15). On mielenkiintoista havaita, että edellä luvussa 4.1 olevan esimerkkilauseen (3) alkuosaan ei ole lisätty lisäsubjektia se infinitiivisubjektin ja adjektiivin vaikea edelle.

(12) [---] tullut hyvin viluksi ja aurinko on laskenut, Tutikki tietää että Jäärouva tulee piakkoin ja että se on hyvin vaarallinen mennä ulos (espanja, B1)

(13) Konsertit - Toistaiseksi The Archetype soittavat vain Italiassa, koska se on vaikea tehdä konsertteja lomalla. (italia, B1)

(14) Ehkä lomalla on mahdollisia käyn töissä, mutta sitten se on vaikeaa saada työpaikan, koska paljon työantajia eivät etsi työntekijiä vain kahden kuukaukauden. (saksa, B2)

(15) Kun perheessä on monta lapsia, se on melko vaikeaa kasvattaa heitä. (venäjä, B1)

Infinitiivisubjektiin saattaa liittyä samantapaisia jäsennysongelmia kuin seuraavassa alaluvussa tarkasteltavaan sivulausesubjektiin. Molemmissa niissä on prototyyppisestä subjektista poikkeava ja erikoinen subjekti, jota oppija ei välttämättä tunne. Lauseissa ei ole nominatiivimuotoista 
subjektijäsentä verbin edellä, ja lause saattaa vaikuttaa subjektittomalta ja jollakin tavalla vaillinaiselta. Alla olevista tapauksista A-C oppijalle tutuin tapaus on A, jossa se toimii anaforisena pronominina. Oppijan voi olla vaikea hahmottaa, miksi lauseissa $\mathrm{B}$ ja C olla-verbin edellä ei ole se-pronominia subjektina. Suomessa on lauseita, joissa predikaatin edellä oleva teemapaikka on tyhjä, ja koko lause voi olla verbialkuinen.

Infinitiivisubjektit ja lausesubjektit ovat erikoisia, ja opetuskokemukseni perusteella äidinkielistenkin opiskelijoiden on vaikea tunnistaa lauseenjäseniä, koska subjektia määritettäessä on ehkä totuttu etsimään vastauksia $k u k a-$ tai mikä-kysymyksiin. Jatkotutkimuksissa olisi mielekästä myös selvittää, kuinka paljon korrektisti lauseenalkuisia ja ilmisubjektittomia verbejä suomenoppijoiden teksteissä esiintyy.
A) Se on hienoa!
B) On hienoa opiskella suomea.
C) On hienoa, että opiskelet suomea.

\subsection{Lausesubjektit}

Lausesubjektilla ja infinitiivisubjektilla on rakenteellisia ja funktionaalisia yhtäläisyyksiä. Shore (2008: 52) toteaa, että lauseen alussa olevalla verbin ja predikatiivin rakenteella, jota käytetään sekä infinitiivisubjektilausekkeessa (esim. on tyhmää maksaa liikaa) että lausesubjektilauseessa (esim. on hyvä, että näistä asioista keskustellaan), voidaan ilmaista suhtautumista ja mielipidettä.

Infinitiivisubjektillisten lauseiden tavoin aineiston lausesubjektillisiin tapauksiin muodollisen se-subjektin sijoittaneista enemmistö on B1-taitotason oppijoita. Esiintymiä on yhteensä 21, ja niistä vain 1 on A2-tasolla olevan oppijan tuotos. Loput vastaukset jakautuvat siten, että B1-oppijan lauseita on 12, B2-oppijan 6 ja C1-oppijan 2.

Aineistoni lausesubjektillisissa lauseissa sivulausesubjektia edeltää päälause. Päälauseen olla-predikaatin edelle oppijat ovat sijoittaneet lisäsubjektin se. Aineistoesimerkeissäni arvioidaan esimerkiksi asioiden kauheutta (16), tärkeyttä (17 ja 19) tai vaikeutta (18). Esimerkeissä 
(16-19) viitataan kirjoittajan omiin näkemyksiin ja esimerkissä (19) Lutherin näkemyksiin.

(16) En ole varma mitä minun pitää tehdä nyt, mutta se on kauhea, että olemme todella riippuvaiset teknologiasta. (puola, B1)

(17) Minusta se on tärkeä, että kääntäjä pitää kiinni alkuperäiskielestä, siis kääntäjä yrittää kääntää teksi uskollisesti. (unkari, B1)

(18) Minusta se on vaikea naiselle vaihtaa rakauksesta ja jälkestä. (B1, kiina)

(19) Lutherille se oli tärkeä, että myös kansa ymmärsi Raamatun tekstejä ja jumalanpalveluksia (B2, saksa)

Kaikki aineistoni unkarinkielisten suomenoppijoiden muodolliset lisäsubjektit ovat joko lausesubjektillisissa tai infinitiivisubjektillisissa lauseissa, ja kaikkien näiden oppijoiden taitotaso on vähintään B1, kuten esimerkissä 17 edellä. On kiinnostavaa, että unkarin kielessä vastaavantyyppisissä tapauksissa puhekielessä esiintyy demonstratiivipronomini $a z$, kun taas kirjakielessä verbin edellä ei ole pronominia. Unkarinkielisten suomenoppijoiden lisäsubjektit lausesubjektien yhteydessä voivat olla merkki puhutun unkarin vaikutuksesta tai toisaalta koulussa opittavien englannin ja saksan vaikutuksesta. (Varga 2017) Unkarin kielessä säätilaa ilmaisevat lauseet ovat subjektittomia suomen kielen tavoin (Seilonen 1995: 153).

Kuten infinitiivisubjekteistakin myös lausesubjekteista voi todeta, oppimisen edistyneemmässä vaiheessa (vrt. Siitonen \& Martin 2012) monipuolisemmat lauserakenteet ja virkkeet tuottavat myös konteksteja, joihin oppija pyrkii sijoittamaan muodollisen subjektin. Opintojen edetessä lauserakenteet, yhdyslauseiden käyttö ja virkkeiden pituus laajenevat, mikä todennäköisesti aiheuttaa myös sen, että alkeistasoa edistyneemmät oppijat tuottavat lauseita, joissa muodollinen se-subjekti on lisätty infinitiivisubjektin tai sivulausesubjektin yhteyteen.

Demonstratiivipronomini se voi luonnollisesti esiintyä lauseissa viittaamassa johonkin edellä mainittuun, mutta muodollisena subjektina sitä (yleiskielessä) ei käytetä niissä yhteyksissä, joihin oppijat tutkimusaineistoni lauseissa ovat pyrkineet sen sijoittamaan. 


\section{Lopuksi}

Suomessa on useita tapauksia, joissa prototyyppisen subjektin puuttuminen houkuttelee suomenoppijaa lisäämään se-pronominin muodolliseksi lisäsubjektiksi. Virikkeenä tähän voi toimia hänen äidinkielensä tai muut kielet, joissa suomen kielelle ominaisia subjektittomia rakenteita ei ole tai joissa esiintyy pronomineja muodollisen subjektin tehtävässä. Se-pronomini on näissä tapauksissa epäreferentiaalinen ja semanttisesti tyhjä subjektiargumentti, joka täyttää verbinetisen paikan. On mahdollista, että äidinkielen mallin lisäksi tai sijaan lisäsubjektien käyttöön vaikuttaa esimerkiksi laajasti opiskeltavan ja osattavan englannin kielen malli.

Muodolliset lisäsubjektit löytyvät aineistossani juuri sellaisista lauseista, joissa perussubjektia ei ole. Aineistossani näin on esimerkiksi Ulkona on kaunista -tyyppisissä tilalauseissa, joissa adverbiaalialkuiseen lauseeseen ei kuulu subjektia ja joissa on tilaa ja olosuhteita kuvaava predikatiivi. Vaikeasti hahmottuvia ovat myös sivulause- ja infinitiivisubjektit: oppija voi pyrkiä lisäämään olla-verbin eteen se-subjektin, vaikka olla-verbiä seuraa subjektitäydennyksenä infinitiivi tai sivulause. Vaikuttaisi siltä, että joissakin konteksteissa muodollisia lisäsubjekteja esiintyy monilla taitotasoilla, kun taas toiset liittyvät selvemmin tiettyyn taitovaiheeseen. Kaiken kaikkiaan tilalauseista etenkin säätilan ilmauksissa on eniten opintojensa alkupuolella olevien opiskelijoiden lauseita, kun taas lause- ja infinitiivisubjektillisia virkkeitä rakentavat tyypillisesti jo opinnoissaan pidemmällä olevat. Eniten koko aineistoni lauseissa on B1-taitotasolla olevien suomenoppijoiden lauseita. Suomen kielen opintojen edetessä suomenoppija saa käsityksen suomen subjektin tyyppitapauksista ja subjektittomista lauseista. Kuitenkin suomenoppijan voi olla vaikea muistaa, että suomessa subjektin paikka voi jäädä tyhjäksi tai subjekti voi esiintyä epätyypillisellä paikalla tai olla muu kuin nominatiivimuotoinen NP. Lisäsubjekti se suomen kielen rakenteen vastaisesti tai epäodotuksenmukaisesti käytettynä vaikuttaa kielen sujuvuuteen ja idiomaattisuuteen kielitaidon eri tasoilla. Subjektittomuus, 
prototyyppiset subjektit ja epäprototyyppiset subjektit liittyvät tiiviisti toisiinsa. Suomenoppijalle on tärkeää erilaisten lausetyyppien ja niissä esiintyvien täydennysten hahmottaminen.

Suomessa se esiintyy puhutussa kielessä muodollisen subjektin kaltaisessa tehtävässä ja sillä on monenlaisia funktioita ja käyttökonteksteja. Voinee ajatella, että esimerkiksi ulkomailla suomea opiskelevat tuskin puhesuomen perusteella lisäävät $s e$-pronominia muodolliseksi subjektiksi lauseisiin, joihin ne eivät kieliopillisesti kuulu. On kuitenkin oleellista, että oppijat kaikissa oppimiskonteksteissa saavat tietoa puhutun ja kirjoitetun kielen ilmiöistä ja niiden suhteista.

Aineistoni kattaa erityyppisiä tapauksia, ja tarkoitukseni on ollut saada yleiskuva erilaisista muodollisen lisäsubjektin lauseista oppijansuomessa. Tutkimustulosten ja aiempien havaintojeni innoittamana pidän tarkoituksenmukaisena laajentaa tutkimusta eri tyyppien yksityiskohtaisempaan tarkasteluun. Esimerkiksi erilaiset subjektittomat tilalauseet tarjoaisivat tutkittavaa taitotasoittain sekä moniäidinkielisen oppijanaineiston että kielikohtaisemman kontrastoinnin avulla.

\section{Lähteet}

CEFR = Common European Framework for Languages: Learning, Teaching, Assessment. Cambridge: Cambridge University Press, 2006.

Croft, William 2001. Radical Construction Grammar: Syntactic Theory in Typological Perpective. Oxford: Oxford University Press. https://doi. org/10.1093/acprof:oso/9780198299554.001.0001

Eriksen, Pål K., Seppo Kittilä, Leena Kolehmainen 2015. The world is raining: Meteorological predicates and their subjects in a typological perspective. Marja-Liisa Helasvuo, Tuomas Huumo (Eds.), Cognitive and Interactional Perspectives on Non-Canonical Subjects. Constructional Approaches to Language. Amsterdam: John Benjamins, 205-228.

Hakanen, Aimo 1972. Normaalilause ja eksistentiaalilause ['Normal sentence and existential sentence']. - Sananjalka 14, 36-76.

Hakulinen, Auli 1975. Suomen sitä: pragmatiikan heijastuma syntaksissa ['The syntax and pragmatics of Finnish sitä']. - Sananjalka 17, 25-41.

Helasvuo, Marja-Liisa, Marjut Johansson 2008. Construing reference in context: Non-specific refernce forms in Finnish and French discussion 
groups. - Maria de los Ángeles Gómez González, J. Lachlan Mackenzie, Elsa M. González Álvarez, Elsa M. (Eds.), Current Trends in Contrastive Linguistics. Functional and Cognitive Perspectives. Studies in Functional and Structural Linguistics 60. Amsterdam: John Benjamins Publishing Company, 27-57.

Helasvuo, Marja-Liisa, Lea Laitinen 2006. Person in Finnish: Paradigmatic and syntactic perspectives. - Marja-Liisa Helasvuo, Lyle Campbell (Eds.), Grammar from the Human Perspective: Case, Space, and Person in Finnish. Current Issues in Linguistic Theory. Amsterdam: John Benjamins Publishing Company, 173-208. http://doi.org/10.1075/cilt.277

Helasvuo, Marja-Liisa, Tuomas Huumo 2010. Mikä subjekti on? ['On the subject of subject in Finnish'] - Virittäjä 114, 165-195.

Holmberg, Anders, Urpo Nikanne 2002. Expletives, subjects and topics in Finnish. - Peter Svenonius (Ed.), Subjects, Expletives, and the EPP. Oxford Studies in the Compartive Syntax. Oxford: OUP, 71-105.

ICLFI = International Corpus of Learner Finnish. Kansainvälinen oppijansuomen korpus. Kielipankki. http://urn.fi/urn:nbn:fi:lb-20140730163

Ivaska, Ilmari 2013. Lausetyyppien sekoittuminen edistyneessä oppijansuomessa: Näkökulmana eksistentiaalilause ['Clause type confusion in advanced learner Finnish: existential sentence as our perspective']. - Lähivõrdlusi. Lähivertailuja 21, 65-85. https://doi.org/10.5128/LV21.03

Ivaska, Ilmari 2014. Mahdollisuuden ilmaiseminen S1-suomea ja edistynyttä S2-suomea erottavana piirteenä ['Expressions of possibility as a distinguishing feature between L1-Finnish and advanced L2-Finnish']. Lähivõrdlusi. Lähivertailuja 24, 47-78. https://doi.org/10.5128/LV24.02

Ivaska, Ilmari 2015. Edistyneen oppijansuomen konstruktiopiirteitä korpusvetoisesti: avainrakenneanalyysi ['Corpus-driven Approach towards Constructional Features of Advanced Learner Finnish: Key Structure Analysis']. Turun yliopiston julkaisuja C 409. Turku: Turun yliopisto. http://urn.fi/ URN:ISBN:978-951-29-6204-4

Jantunen, Jarmo Harri 2011. Kansainvälinen oppijansuomen korpus (ICLFI): typologia, taustamuuttujat ja annotointi ['International corpus of learner Finnish (ICLFI): typology, variables and annotation']. - Lähivõrdlusi. Lähivertailuja 21, 86-105. https://doi.org/10.5128/LV21.04

Jantunen, Jarmo Harri 2015. Oppimiskontekstin vaikutus oppijanpragmatiikkaan: astemääritteet leksikaalisina nallekarhuina ['Learning context and its effect on learner pragmatics: degree modifiers as lexical teddy bears']. Lähivõrdlusi. Lähivertailuja 25, 105-136. https://doi.org/10.5128/LV25.05 
Kajander, Mikko 2013. Suomen eksistentiaalilause toisen kielen oppimisen polulla ['Paths of learning Finnish existential sentences']. Jyväskylä Studies in Humanities 220. Jyväskylä: Jyväskylän yliopisto. http://urn.fi/ URN:ISBN:978-951-39-5530-4

Kolehmainen, Leena 2010. Sääverbien syntaksia ja semantiikkaa ['The syntax and semantics of meteorological verbs']. - Virittäjä 114, 5-38.

Laine, Jenni 2013. Onko suomen kieli helppo vai helppoa? Suomenoppijoiden predikatiivit kopulalauseessa. Pro gradu -tutkielma. Turku: Turun yliopisto.

Laitinen, Lea 1995. Nollapersoona ['The zero person']. - Virittäjä 99, 337-358.

Löflund, Juhani 1998. Suomen kirjoitetun yleiskielen passiivi ['The passive in standard written Finnish']. Turku: Åbo Akademis förlag.

Seilonen, Marja 1995. Suomen subjektittomien lauseiden vastineita unkarissa. Hungarologische Beiträge 3, 151-165.

Seilonen, Marja 2013. Epäsuora henkilöön viittaaminen oppijansuomessa ['Indirect references in Finnish learner language']. Jyväskylä Studies in Humanities 197. Jyväskylä: Jyväskylän yliopisto. http://urn.fi/ URN:ISBN:978-951-39-5025-5

Shore, Susanna 2008. Lauseiden tekstuaalisesta jäsennyksestä ['The textual organisation of clauses']. - Virittäjä 112, 24-65.

Siitonen, Kirsti 2012. Nollapersoonalauseet edistyneen suomenoppijan käytössä ja tulkittavina ['Zero person -sentences and advanced students of Finnish']. Sananjalka 42, 157-166.

Siitonen, Kirsti, Maisa Martin 2012. Suomen kielen U-verbit taitotason indikaattorina ['U-system verbs as indicators of proficiency level']. - Lähivõrdlusi. Lähivertailuja 22, 369-406. https://doi.org/10.5128/LV22.13

Suomen mestari 1 = Gehring, Sonja, Sanni Heinzmann 2012. Suomen kielen oppikirja aikuisille. Helsinki: Finn Lectura.

Suomen mestari 2 = Gehring, Sonja, Sanni Heinzmann 2013. Suomen kielen oppikirja aikuisille. Helsinki: Finn Lectura.

Svenonius, Peter 2002. Introduction. - Peter Svenonius (Ed.), Subjects, Expletives, and the EPP. Oxford Studies in the Compartive Syntax. Oxford: OUP, 3-29.

Tarvainen, Kalevi 1985. Kielioppia kontrastiivisesti: Suomesta saksaksi. Saksan kielen laitoksen julkaisuja 4. Jyväskylä: Jyväskylän yliopisto.

Tenhonen-Lightfoot, Erja 1992. Aspekte der Andere am Beispiel von finnischen und deutschen Bankdienstleistungs- und Telekommunikationsprospekten. Julkaisematon lisensiaatintutkielma. Vaasan yliopisto.

Varga, Judit 2017. Henkilökohtaisessa sähköpostikeskustelussa saatu informaatio 14.8. ['Email']. 
Vilkuna, Maria 1996. Suomen lauseopin perusteet ['Fundamentals of Finnish Syntax']. Edita: Helsinki.

VISK = Hakulinen, Auli, Maria Vilkuna, Riitta Korhonen, Vesa Koivisto, Tarja Riitta Heinonen, Irja Alho 2008. Iso suomen kielioppi ['Grammar of Finnish’]. Verkkoversio. SKS:n toimituksia 950. Helsinki: Suomalaisen Kirjallisuuden Seura. http://scripta.kotus.fi/visk (1.6.2017).

White Leila, 2010. Suomen kielioppia ulkomaalaisille ['Finnish Language for Foreigners']. 8. painos. Helsinki: Finn Lectura.

\section{Hanna Jokela}

suomen kieli, kieli- ja käännöstieteiden laitos

20014 Turun yliopisto, Finland

hanna.jokela@utu.fi 


\title{
Formal subject se from a Finnish learner's viewpoint
}

\author{
HANNA JOKELA \\ University of Turku
}

\begin{abstract}
This article focuses on formal subjects in Finnish as a foreign language learners' texts. My aim is to study sentences, which in Finnish are subjectless, or have a non-typical subject. Prototypical subject in Finnish is in nominative, agrees with the predicate, and is in preverbal position. In Finnish, however, there are plenty of subjectless constructions and clause types, for example different expressions of weather and state. In Finnish, formal subjects are not part of these constructions. There are also non-typical subjects, such as clausal and infinitival subjects, or partitive subjects in existential clauses. Unlike in many Indoeuropean languages, in standard Finnish, there are no formal subjects (also known as expletives), which are non-referential, "sematically empty", and formally fulfil the role of subject.

Based on my earlier teaching experiences and this study, learners of Finnish tend to add a formal subject, an additional and unnecessary subject, in clauses which in Finnish actually are naturally subjectless, or have a subject which is not a prototypical nominative subject. Multifunctional, diverse and familiar pronoun $s e$ is applied by learners in case they have decided to add an additional subject argument.

My data comes from International Corpus of Learner Finnish (ICLFI). Majority, $61 \%$, of formal subject clauses in my data are produced by learners on language skill level B1 or B2. My aim is to provide an overview on additional formal se-subject in learners' written Finnish. Formal subjects are known in many language, whereas in Finnish there is a variety of subjectless constructions. This phenomen is interesting from a point of view of Finnish syntax, and learners' language.
\end{abstract}

Keywords: expletive; infinitival subject; L2; subjectless; syntax; Finnish language 